\title{
Література
}

1. Кобринська М. Українське шкільництво в Коломиї / М. Кобринська // Коломия. Електронний ресурс. - Режим доступу: http://kolomyya.org/histpub /historypub50.htm 2. Кузьмович В. Українська шкільна політика (у скороченні) / В. Кузьмович // Перший український педагогічний конгрес, 1935. - Львів: Накладом товарства «Рідна школа», 1938. - 252 с. - С. 198-201. 3. Курляк I. Розвиток класичної освіти на західноукраїнських землях (XIX-перша половина XX ст.): дис. ... д-ра пед. наук: 13.00.01 / І. Курляк; Інститут педагогіки і психології професійної освіти АПН України. К., 2000. - 473 с. 4. Надпрутянський М. Проєкт єдиної школи в Україні / М. Надпрутянський // Шлях виховання і навчання. - Кн.1, 1938. - Січень-лютий-березень - С. 1-6. 5. Наукові програми в народних школах третього ступеня для дітей української національності //Шлях навчання й виховання. -1934. - кн.1. - С. 7-73. 6. Пометун О. Методика навчання історії в школі / О. Пометун, Г. Фрейман. - К.: Генеза, 2005. - 328 с. 7. Пометун О. Навчання історії без пристрастей і пересудів / О. Пометун // Історія в школах України. - 2002. - № 4. - С. 7-11. 8. Резолюції і постанови Першого українського педагогічного конгресу // Перший український педагогічний конгрес, 1935. - Львів: Накладом товариства «Рідна школа», 1938. - 252 с. - С. 236-249. 9. Стинська В. Система шкільництва в Галичині (кінець XIX - початок XX ст.): дис. ... канд. пед. наук: 13.00 .01 / В. Стинська; Прикарпатський ун-т ім. Василя Стефаника. - Івано-Франківськ, 2004 - 243 с. 10. Сухомлинська О. В. Реформаторська педагогіка / О. В. Сухомлинська // Енциклопедія освіти / Акад. пед. наук України; головний ред. В. Г. Кремень. - К. : Юрінком Інтер, 2008. - С. 774. 11. Nowaczyk S. Rysunekjko ilustracja historji / S. Nowaczyk // Przyjaciel szkoly. - 1929. - S. 570-574.

УДК [378.147:371.26](94)

Тамара Семенченко

\section{ТЕХНОЛОГІЯ ОЦІНЮВАННЯ В СИСТЕМІ ПЕДАГОГІЧНОЇ ПРОФЕСІЙНОЇ ОСВІТИ АВСТРАЛЇ̈}

Семенченко Т. О. Технологія оцінювання в системі педагогічної професійної освіти Австралії.

У статті розглянуто компоненти технології оцінювання в педагогіці вищої школи Австралії. Охарактеризовано теоретико-філософські підходи до оцінювання навчальної діяльності та зв'язку оцінювання з професійною підготовкою майбутніх учителів Австралії.

Ключові слова: оцінювання у вищій школі, формативне та підсумкове оцінювання, завдання для оцінювання майбутніх учителів.

Семенченко Т. А. Технология оценивания в системе педагогического профессионального образования Австралии.

В статье рассмотрены компоненты технологии оценивания в педагогике высшей школы Австралии. Охарактеризированы теоретико-философские подходы к оцениванию учебной деятельности и взаимосвязи оценивания и профессиональной подготовки будущих учителей Австралии.

Ключевые слова: оценивание в высшей школе, формативное и итоговое оценивание, задания для оценивания будущих учителей.

Semenchenko T. O. The assessment technics in the system of teacher professional education in Australia.

The constituent parts of the assessment technics in the system of higher education in Australia are viewed in the article. Theoretic and philosopfic approaches to learning and teaching assessment and the correlation between the assessment and the initial professional teacher training in Australia were characterised.

Key words: assessment in higher education, formative and summative assessment, assessment tasks for future teachers.

Проблема якості освітніх послуг є однією з визначальних для системи освіти будь-якої країни, зокрема й України. В аналітичній записці Національного інституту стратегічних досліджень при Президентові України «Свропейський досвід для створення ефективної системи контролю та оцінки якості вищої освіти» зазначено, що «жоден із чисельних українських ВНЗ не входить до 500 кращих університетів світу за провідними світовими 
рейтингами. Для порівняння, в Австралії серед 39 університетів 8 входять до 200 кращих університетів світу» [1].

Суспільна відповідальність вищих навчальних закладів Австралії щодо забезпечення належної якості освітніх послуг забезпечується конструктивним оцінюванням навчальних програм, курсів, завдань, професійно-педагогічних вмінь викладачів та вчителів, навчального соціуму, теоретико-філософських засад побудови освіти. Провідними науковцями-державними діячами Австралії Анжелою Скаріно та Антоніо Лідіокоат в останні роки XXI століття закладено принципово новий підхід до практики оцінювання [5]. У педагогіці зв'язок навчання 3 оцінюванням розглядається у системі: оцінювання з навчання, оцінювання для навчання та оцінювання як навчання. Ще у 1990-х-початку десятиліття 2000-х років акцент робився на оцінюванні з навчання, доки світові науковці не довели, що оцінювання для та як навчання може підвищити рівень досягнень учнів. У цьому аспекті досвід Австралії становить наукову цінність для України.

У працях російських та українських науковців розкривались лише окремі аспекти розвитку національної системи освіти країни Австралії: реформування шкільної освіти (А. Волкова), робота 3 обдарованими дітьми в державній системі освіти Австралії (А. Переверзєв), полікультурність освіти вчителів (Л. Голуб), тенденції реформування вищої освіти (С. Корєшкова). Питання оцінювання досліджувалися багатьма науковцями, зокрема А. Акселюк, С. Вітвицькою, А. Кузьмінським, В. Лозовою, М. Фіцулою та ін. Водночас проблема технології оцінювання у системі професійної педагогічної освіти в Австралії не знайшла досі вичерпного висвітлення в наукових дослідженнях.

Meта статті - охарактеризувати технологію оцінювання в педагогіці вищої школи Австралії; показати форми підготовки майбутніх учителів мов в аспекті технології оцінювання.

В австралійській педагогіці розрізняють два поняття в межах оцінювання: це англійське assessment та evaluation [4, с. 200]. Під першим розуміється збір інформації про навчальні досягнення учнів, який може виражатися у кількісних та якісних показниках. Метою цього виду оцінювання $є$ підтримка зворотного зв'язку зі студентами про їхній прогрес та розвиток, виставлення оцінок, вибір навчально-педагогічних засобів. Другий термін відноситься до визначення ціннісної вагомості навчального процесу, зокрема навчальних програм, курсів, занять, учителів, навчальних посібників тощо. Завданням такого виду оцінювання є сприяння зростання навчальних досягнень учнів [3, с. 14].

Оцінювання у розумінні assessment складається 3 двох ключових аспектів: формативного (formative) та підсумкового (summative). Завданням формативного оцінювання $\epsilon$ власне навчання, сприяння у досягненні інтелектуального, духовного поступу, а підсумкове навчання спрямоване на підведення результатів досягнень. Доречність застосування формативного оцінювання полягає у мотивуванні учнів, наданні фідбеку для поліпшення навчання, діагнозі сильних та слабких сторін учнів, допомозі учням конструктивно оцінювати та аналізувати результати своєї діяльності. На противагу формативному підсумкове оцінювання націлене на виставлення оцінки (зараховано чи не зараховано, балу), формування рейтингу успішності студентів, прогнозування можливого майбутнього успіху студента на інших курсах або працевлаштуванні.

Підготовка майбутніх учителів передбачає формування високоморальних, інноваційних, мислячих, мотивованих, завзятих, впевнених, цікавих, натхненних, конкурентоздатних фахівців. Перед педагогічним колективом факультетів освіти постає питання, як виміряти та оцінити морально-етичне світобачення, міжкультурну толерантність та політичну коректність, уміння студентів аналізувати власний досвід, працювати та саморозвиватися, креативно та відповідально ставитися до процесу навчання учнів та багато інших якостей, необхідних для вчителя. Оцінити рівень знання чи володіння мовою набагато легше, оскільки слово «книга» має свій еквівалент німецькою, французькою, японською, і він один. У педагогіці ж немає єдиної правильної відповіді на питання, іноді навіть висококваліфікований викладач віднаходить іï разом зі студентами і отримує задоволення від того, що саме учні знайшли раціональний варіант. Таке бачення зумовлює появу своєрідних видів завдань для формативного та підсумкового оцінювання студентів.

Ще одним аргументом на користь обгрунтування доцільності використання нестандартних завдань для формативного та підсумкового оцінювання $\epsilon$ їх практична значущість. Коли 
майбутні вчителі прийдуть до школи, чи то на практику, чи як дипломовані фахівці, від них вимагатимуть розробити навчальний модуль, підготувати урок, провести анкетування, вести портфоліо, випустити журнал або збірник, провести презентацію, науково-дослідний проект, співпрацювати з батьками.

Завдання для оцінювання можуть бути найрізноманітнішими: есе, проекти, усні презентації, рольові ігри, кейси, квізи, портфоліо та інші.

Стажування в університеті Сіднея на факультеті освіти та соціальної роботи надало змогу проаналізувати навчальні завдання студентів бакалаврату для підсумкового оцінювання. Було виявлено, що до всіх видів завдань ставилися вимоги щодо кінцевого терміну подання виконаного завдання, сутності завдання, надавалися критерії оцінювання, розподіл академічних балів за частинами завдання. Спільними критеріями оцінювання визначалися такі: своєчасність подання, відповідність темі та формату завдання, відсутність орфографічних, пунктуаційних, граматичних помилок, логічність, ясність та послідовність викладу. Зупинимося на детальному огляді видів завдань для двох семестрів [6; 7].

У першому семестрі майбутні вчителі початкової школи виконують два завдання: портфоліо та плани уроків. Обидва завдання $є$ рівноцінними за кількістю максимально можливо набраних балів. Кожне із завдань повинно розкриватися у межах 2500 слів. Завдання для портфоліо формулювалося так: розробити портфоліо, яке окреслює особисті та професійні аспекти навчання мови в початковій школі, та зв'язок із особистим досвідом. 3-поміж інших критеріїв оцінювання називався зв'язок змісту портфоліо 3 відповідними місцевим, регіональним та національними стандартами в галузі освіти. Змістовий склад портфоліо повинен вміщувати такі підсекції: короткий огляд біографії, особиста думка 3 питання навчання мов, резюме останніх базових досліджень щодо навчання іноземних мов у початковій школі, короткий огляд відповідних нормативно-правових документів та навчальних планів, виклад бачення доречної педагогіки для навчання мов у початковій школі, розкриття сутності взаємозв'язку грамотності між першою та другою мовами, перелік доречних ресурсів на дидактичних матеріалів для навчання іноземної мови у початковій школі, формулювання положень щодо того, як здобуті в результаті дослідження знання будуть залучені до практики.

Сутність завдання 3 планування уроків полягала у підготовці трьох взаємопов'язаних уроків 3 мови для початкової школи. Виконане завдання має містити власне плани уроків, допоміжний матеріал та бібліографію.

У другому семестрі навантаження на завдання для остаточного оцінювання розподілялося таким чином: Міжкультурне завдання. Частина $1-40 \%$, Міжкультурне завдання. Частина 2 $40 \%$, Презентація для батьків у Power Point - $20 \%$. Для виконання першої частини Міжкультурного завдання студентам необхідно було обрати дві книги (два журнали) для читання для молодших читачів іноземною мовою та розробити завдання, за допомогою яких учні зможуть здобути знання про міжкультурні зв'язки. По-перше, необхідно зробити короткий (150 слів) виклад змісту кожної історії англійською мовою, включивши видавничі відомості. По-друге, написати стисле резюме (150 слів) про групу учнів, зазначивши власну роль у цій групі (вчитель, класний керівник). Далі - показати логічне обгрунтування (150 слів), чому обрана книга/журнал буде доречною для визначеної групи учнів. По-четверте, розробити 5 завдань для кожного текстового ресурсу, спрямованих на розвиток використання лексики, міжкультурних та міжмовних зв'язків. При цьому визначити, що завдання слід давати для індивідуальної роботи, виконання в парах або групах, для всього класу. Нарешті, подати вказівки та ресурси, які можна використовувати для підвищення складності навчання, та детально окреслити кроки виконання завдання окремо для учнів та вчителів.

Виконання другої частини міжкультурного завдання необхідно було розробити завдання для оцінювання сформованості міжкультурного розуміння (5 завдань для оцінювання відповідно до 5 завдань Частини 1). Керівником визначено кроки роботи над завданням: розробити бланк оцінювання, надати логічне обгрунтування доцільності кожного завдання для оцінювання, вмістити перелік додаткових ресурсів, які допоможуть учням виконати завдання та зазначити список джерел, використаних під час виконання певного завдання.

Презентація для батьків полягала у розробленні 6 слайдів, супроводжуваних усним текстом щодо теорії, дослідження та практики навчання іноземної мови в початковій школі. Повний усний текст бесіди має не виходити за межі 6 слайдів. Критеріями оцінювання визнавалися 
старанність виконання, дизайн та естетичний вигляд слайдів, наявність розкриття п’яти понять 3 посиланням на наукову літературу.

У висновку зазначимо, що в педагогіці вищої школи Австралії оцінювання використовується як потужний інструмент навчання студентів та забезпечення якості навчальних програм і рівня підготовки фахівців. Упродовж курсу навчання студентів формативне оцінювання здійснюється у формі миттєвого фідбеку, окрім професійноособистісних умінь, знання та навички здобуваються в результаті роботи над завданнями для підсумкового оцінювання кожного семестру. Перспективним напрямом подальших розвідок $€$ розроблення методичних рекомендацій з питань імплементації нових видів завдань для оцінювання в умовах української вищої школи.

\section{Література}

1. Свропейський досвід для створення ефективної системи контролю та оцінки якості вищої освіти в Україні. Аналітична записка [Електронний ресурс] / М. Карпенко // Інститут стратегічних досліджень при Президентові Україні. - Режим доступу: http://www.niss.gov.ua/articles/745/ 2. Black P. \& Jones J. 'Formative assessment and the learning and teaching of MFL: sharing the languages learning road map with the learners', in Language Learning Journal, 34, Issue 1, 4-9. Reprinted by permission of the publisher, Taylor \& Francis Ltd, 2006. 3. Brookhart S. M. Assessment theory for college classrooms. New directions for teaching and learning, 2009. - 100 p. 4. Learning and Teaching in Higher Education. The reflective professional. Second Edition. Greg Light, Roy Cox, Susanna Calkins. TJ International Ltd, Padstow, Cornwall, 2009. 5. Teaching and Learning Languages. A Guide. Angela Scarino, Anthony J Liddicoat. Funded by the Australian Government Department of Education, Employment and Workplace relations. -100 p. 6. The University of Sydney. Faculty of education and Social Work. EDUP4007. Primary Languages A. Unit of Study Outline, Session 1, 2012. 7. The University of Sydney. Faculty of education and Social Work. EDUP4008. Primary Languages B. Unit of Study Outline, Session 2, 2012.

УДК 37(09):008

Марина Сіренко

\section{КОНЦЕПТ МАТЕРИНСТВА ЯК СКЛАДНИК ПЕДАГОГІЧНОЇ КУЛЬТУРИ СУСПІЛЬСТВА}

Сіренко М. В. Концепт материнства як складник педагогічної культури суспільства.

Стаття присвячена аналізу стану вивчення концепту материнства як складника педагогічної культури суспільства, окресленню його педагогічних функцій. Концепт материнства розуміється як когнітивна засада жіночого та чоловічого світовідношення, практичної поведінки, культурної діяльності та як складник сучасної педагогічної культури суспільства.

Ключові слова: материнство, концепт материнства, педагогічна культура, педагогічні функції, суспільство.

Сиренко М. В. Концепт материнства как составляющая педагогической культуры общества.

Статья посвящена анализу состояния изучения концепта материнства как составляющей педагогической культуры общества, выделению его педагогических функций. Концепт материнства рассматривается как когнитивная основа женского и мужского соотношения, прктического поведения, культурной деятельности и как составляющая современной педагогической культуры общества.

Ключевые слова: материнство, концепт материнства, педагогическая культура, педагогические функции, общество.

Sirenko M. V. The concept of Motherhood as a component of society pedagogical culture.

The article is devoted to the analysis of the concept Motherhood as a component of society pedagogical culture, outlines its educational functions. The concept of motherhood is understood as a cognitive principle of woman's and man's outlook, practical behavior, cultural activities and as a component of modern society educational culture.

Key words: Motherhood, the concept of Motherhood, pedagogical culture, pedagogical functions, society. 